\title{
LUCYNA MYSZKA-STRYCHALSKA
}

Uniwersytet im. Adama Mickiewicza

w Poznaniu

\section{OBRAZ MŁODZIEŻY W FILMIE - JAKO IMPULS DO NAMYSEU NAD KONDYCJĄ TOŻSAMOŚCI WSPÓŁCZESNYCH NASTOLATKÓW}

\begin{abstract}
Aвstract. Myszka-Strychalska Lucyna, Obraz młodzieży w filmie - jako impuls do namystu nad kondycja tożsamości wspótczesnych nastolatków [The Picture of Young People in Film as an Impulse to Considering the Condition of the Identity of Modern Teenagers]. Studia Edukacyjne nr 44, 2017, Poznań 2017, pp. 209-230. Adam Mickiewicz University Press. ISSN 1233-6688. DOI: 10.14746/se.2017.44.13

The dynamic transformations of the contemporary reality oblige the subject to engage in permanent self-creation and search of their place in the world. Technological development and the increasing role of the pictorial message in socio-cultural life significantly impact the individual's perception of the external environment. A wide film offer, an essential element of popular culture, creates both a fictional image of the postmodern world and strives to reflect its real image, including the youth participating in its space. In the face of this sketched perspective, a question arises: "To what extent is the image of a young man shown in films consistent with his real face?" and "To what extent does the image of a teenager in a movie affect his own 'ego'"?
\end{abstract}

Key words: youth, film, present, identity

Dynamika przemiany współczesnej rzeczywistości sprawia, że staje się ona pozbawiona trwałych znaczeń. Niestabilność oraz towarzyszące jej poczucie niepewności obligują jednostkę poszukującą swojego miejsca w świecie do kształtowania własnego światopoglądu, a w konsekwencji także tożsamości opartej na fragmentarycznych przesłankach, niejednokrotnie o ambiwalentnym charakterze. Mnogość różnorodnych informacji docierających do podmiotu przyczyniła się do tego, iż zaczął on postrzegać swoje otoczenie przez pryzmat obrazów, których znaczenie społeczno-kulturalne zostało wzmocnione poprzez oddziaływanie mediów oraz postęp technologiczny. Niniejszą prawidłowość zauważył między innymi P. Celiński, stwierdzając, iż 
tekstocentryczne analizy kondycji nowych mediów, które postrzegają hipertekstualność jako najważniejszy z kulturowych kształtów cyfrowości, wraz z rozwojem technologicznym przesunęły się na drugi plan, ustępując miejsca obrazom i ustanowionej w oparciu o ich język kulturze wizualnej ${ }^{1}$.

Partycypujący w tak skonstruowanej przestrzeni człowiek staje się podmiotem sprawczym, samorefleksyjnym, odpowiedzialnym za przebieg własnej biografii, kształtowanej na podstawie zarówno realnych doświadczeń, jak i przeżyć generowanych za pośrednictwem mediów. Funkcjonuje w świecie o podwójnej naturze społeczno-przestrzennej, umożliwiającej mu bycie $\mathrm{w}$ danym miejscu i czasie oraz jednocześnie $\mathrm{w}$ innej, nawet odległej płaszczyźnie, do której dociera za pomocą nowoczesnych rozwiązań technicznych. Sytuacja ta przyczynia się do zacierania granicy pomiędzy realną oraz fikcyjną rzeczywistością, co może pozbawiać jednostkę zdolności ich odróżniania.

Konglomerat nakreślonych przeobrażeń nie pozostaje bez znaczenia przede wszystkim dla ludzi młodych, identyfikujących własne aspiracje oraz cele życiowe. Przyglądanie się tym uczestnikom życia społecznego ma istotną kognitywnie wartość, ze względu na fakt, iż to właśnie młodzież jest „bardzo dobrym punktem odniesienia do obserwacji tego, co dzieje się z całym społeczeństwem" ${ }^{2}$, ponieważ „dzięki swej młodości i dynamice może stawać się czynnikiem zmiany społecznej i wywierać wpływ na przemiany całego społeczeństwa" ${ }^{3}$. Nie ulega wątpliwości, iż okres dojrzewania stanowi czas intensywnych przemian dla jednostki dokonujących się w sferach biologicznej, psychicznej, społecznej i kulturowej, co sprawia, że adolescent przygotowujący się do dorosłego życia wyróżnia się wysokim stopniem ciekawości poznawczej chcąc dookreślić siebie. Znaczącym czynnikiem dla kreowania własnego „ja" może być dla niego telewizja, Internet oraz emitowane w nich filmowe opowieści, prezentujące mnogość stylów życia, ideałów oraz wydarzeń przeżywanych przez bliskich im bohaterów.

Z. Bauman dostrzegał istotną moc słowa pisanego, opowiadając się za stwierdzeniem, że „duch powieści zawsze wyprzedza o krok ociężałe ciało teorii". Warto zauważyć, iż literatura niejednokrotnie staje się inspiracją dla filmów, które również prezentują określony układ zdarzeń, będących wizją jakiegoś wycinka rzeczywistości kreowanego przez jego twórców. Film z pewnością można uznać za jeden z integralnych elementów kultury masowej, który wraz z postępem technologicznym ulega znaczącym przeobrażeniom. Począt-

${ }^{1}$ P. Celiński, Postmedia. Cyfrowy kod i bazy danych, Lublin 2013, s. 156.

${ }^{2}$ K. Szafraniec, M. Boni (red.), Młodzi 2011, Warszawa 2011, s. 166.

${ }^{3}$ B. Galas, Młodzież, [w:] Encyklopedia pedagogiczna XXI wieku, red. T. Pilch, t. II, Warszawa 2005, s. 327. 
ków światowej kinematografii dopatruje się u schyłku XIX wieku. Twórcami historii kina zostali okrzyknięci francuscy bracia Auguste i Louis Lumière, którzy w 1895 roku zorganizowali pierwszy publiczny pokaz filmowy. Obecnie ten rodzaj audiowizualnego przekazu dostępny jest nie tylko w kinach, ale również w telewizji oraz sieci internetowej, zaś jego popularność oraz dostępność sprawia, iż zyskuje liczne grono odbiorców. Warto zauważyć, iż „film przenosi się poza własne granice, występuje $\mathrm{w}$ realizacjach wideo, $\mathrm{w}$ formach rzeczywistości wirtualnej, w grach komputerowych" ${ }^{4}$, a zatem w niemalże każdej z form przekazu multimedialnego, co oznacza, że nie pozostaje bez znaczenia dla ich jakości, stosowanego języka oraz praktyk medialnych. Stwierdzenie E. Panofsky' ego $^{5}$ trakujące, iż kino odegrało istotną rolę $\mathrm{w}$ procesie kształtowania języka, zachowania, opinii, smaku, strojów, jak również fizycznego wyglądu publiczności stanowiącej ponad połowę ziemskiej ludności, można uznawać za aktualne. Różnorodne ekranizacje niejednokrotnie odzwierciedlają stosunki społeczno-ekonomiczne będące efektem przemian współczesnego świata, dlatego też analizuje się je w kategoriach zwierciadła jego kultury, rejestratora jej przemian.

Film oddziałuje na odbiorców poprzez szereg bodźców angażujących jednocześnie receptory wzrokowe (barwy, ruch obrazów, układ linii) oraz słuchowe (dialogi, muzyka). Jedną z jego cech charakterystycznych, wyróżniających go spośród innych form sztuki, jest fakt, iż wiernie odtwarza świat rzeczywisty ${ }^{6}$. Oczywiście, przedstawiane w nim sceny mogą stanowić przykład fikcyjnych tudzież zdeformowanych wydarzeń oraz wyimaginowanych interpretacji, jednak emitowane obrazy odznaczają się wysokim stopniem realizmu. Spostrzeżenie to z pewnością wydaje się trywialne, jednak nie pozostaje bez znaczenia dla siły, z jaką wpływa na emocjonalne, poznawcze i motywacyjne zaangażowanie widza. Warto $\mathrm{w}$ tym miejscu przytoczyć słowa B. Kosmalskiej, która stwierdza, iż

wyprodukowane przez nowe media i technologie produkty audiowizualne wtłaczają człowieka w świat imitowanych obrazów i dźwięków, których pochodzenia i fałszywego znaczenia nie rozpoznaje. Współczesny odbiorca jest wabiony i przyciągany perspektywą uczestniczenia i współkreowania kultury medialnej. Spektakularność przejawia się w widowiskowości i efektywności przedstawianych wydarzeń7.

${ }^{4}$ R.W. Kluszczyński, Film, wideo, multimedia. Sztuka ruchomego obrazu w erze elektronicznej, Kraków 2002, s. 21-22.

${ }^{5}$ E. Panofsky, Styl i tworzywo w filmie, [w:] Studia z historii sztuki, red. E. Panofsky, Warszawa 1971, s. 362-378.

${ }^{6}$ J. Plisiecki, Język filmu i jego mowa, Roczniki Kulturoznawcze, 2010, 1, s. 163-164; H. Depta, Fabryka snów czy szkota życia, Warszawa 1986, s. 7.

${ }^{7}$ B. Kosmalska, Zrozumieć obraz, [w:] Obraz, przestrzeń popkultura. Inspiracje badawcze w polu pedagogiki społecznej, red. M. Ejsmont, B. Kosmalska, M. Mendel, Toruń 2009, s. 17. 
Kognitywna analiza oddziaływania filmu na widza oscyluje wokół rozpoznania jego aspektów formalnotreściowych oraz poznawczych predyspozycji odbiorcy, które warunkują jakość jego interpretacji ${ }^{8}$.

W podjętych rozważaniach skoncentrowano się na analizie filmów fabularnych, ponieważ ich realistyczna narracja zyskuje liczne grono sympatyków, a także zgodnie z trafnym spostrzeżeniem H. Depty, ukazują one pierwotną naturę potrzeb i oczekiwań podmiotu ${ }^{9}$. Filmy fabularne stanowią dla widza okazję przeżywania zapośredniczonych doświadczeń, których nie zawsze doznaje $\mathrm{w}$ rzeczywistości, dostarczają mu rozrywki oraz niejednokrotnie są dla niego źródłem wiedzy o świecie, a zatem pełnią funkcję informacyjno-edukacyjną. Dostępność tego utworu audiowizualnego oraz niski stopień wymagań poznawczych wobec odbiorcy przyczyniły się do interpretowania go w kategoriach środka wyrazu kultury masowej. M. Golka uznaje, iż treści kultury masowej

są nie tyle „oknem na świat” (...), są niemal całym kolorowym światem, który zastąpi ten bardziej szary - realny. Jest to świat dość trywialny, płytki, choć banalnie śliczny. Dla wielu ludzi jest właściwie to cały znany im świat - innego nie poznają, nie doświadczają, nie zrozumieją. Ba, dla wielu ludzi jest to w zasadzie cała wiedza i cała refleksja, jakie mogą mieć także o samym sobie. Poza tym osobie znajdującej się w domu spośród wszystkich mediów telewizja daje niezwykłe, choć złudne poczucie łączności $\mathrm{z}$ innymi ludźmi i ze światem ${ }^{10}$.

Przytoczone argumenty uzasadniają, dlaczego warto poddawać refleksji obraz rzeczywistości rekonstruowany w filmach fabularnych. Okazuje się on interesujący poznawczo, nie tyko ze względu na pytanie o stopień zbieżności tego wizerunku ze stanem faktycznym, ale także z powodu siły z jaką oddziałują na światopogląd odbiorcy.

Obraz młodzieży zrekonstruowany w filmach jest bardzo zróżnicowany. Przyczyn takiego stanu rzeczy można dopatrywać się w tym, iż młody człowiek staje się częstym bohaterem ekranizacji, w których prezentowany jest w rozmaitych opowieściach i kontekstach oraz w wielogatunkowości filmu fabularnego, generującej jego różnorodność tematyczną. Oglądowi poddano wybrane produkcje polskie oraz zagraniczne, które interpretowano w sześciu kategoriach rzeczowych. Oczywiście, katalog ten nie stanowi listy zamkniętej, nie zawiera bowiem tytułów wszystkich produkcji filmowych poświęconych adolescentom.

${ }^{8}$ J. Pisarek, P. Francuz, Poznawcze i emocjonalne zaangażowanie widza $w$ film fabularny $w$ zależności od typu bohatera, [w:] Psychologiczne aspekty komunikacji audiowizualnej, red. P. Francuz, Lublin 2007, s. 166.

${ }^{9}$ Patrz: H. Depta, Fabryka snów.

${ }^{10}$ M. Golka, Aparycje wspótczesności, Warszawa 2015, s. 135. 
Pierwsza wyróżniona grupa filmów związana jest ze stylami życia reprezentowanymi przez głównych bohaterów, w które w znacznym stopniu wpisane jest ryzyko, do tego stopnia, iż przyjmują one postać problemów społecznych. Należy wskazać w tym miejscu takie tytuły jak: "Christiane F. - My, dzieci z dworca Zoo", , Requiem dla snu”, ,Cześć Tereska”, ,Trzynastka”, ,Świnki”, "Galerianki", ,"Sponsoring”, , "Studentki”, ,"Sala samobójców”, , „Dziewczyńskie porachunki", „Obietnica”. Zachowania ryzykowne zyskujące również miano problemowych definiuje się jako „, anormatywne, pozostające w opozycji do porządku społecznego i prawnego, stanowiące jednocześnie zagrożenie dla zdrowia i rozwoju jednostki"11. Najczęściej wymienia się wśród nich: używanie substancji psychoaktywnych (palenie tytoniu, spożywanie alkoholu, zażywanie narkotyków, dopalaczy, leków uspokajających), nieprawidłowe odżywanie się, zachowania samobójcze, nieumyślne urazy ciała, przestępczość, przemoc, wandalizm, ciąże nieletnich oraz wczesną inicjację seksualną, ucieczki z domu, porzucenie szkoły (wagary, brak sukcesów edukacyjnych, zaniedbywanie nauki), brak poczucia sensu życia ${ }^{12}$. Należy również zaznaczyć, iż wraz z postępem technologiczno-cywilizacyjnym ich liczba ciągle rośnie.

U. Beck współczesną rzeczywistość nazywa „społeczeństwem ryzyka”13, zaś zgodnie ze spostrzeżeniem Z. Melosika żyjemy w „kulturze skoku adrenaliny i ryzyka"14 - określenia te nie są bez znaczenia, ponieważ oznaczają, iż owe ryzyko nabiera charakteru cywilizacyjnego, staje się coraz bardziej powszechne, uniwersalne w obecnym świecie i obrazuje jego „otwartość na wątpliwą przyszłość, $w$ której jest miejsce na ambiwalencję oraz niezamierzone i nieprzewidywalne wydarzenia" ${ }^{\prime 1}$. Zachowania ryzykowne młodzieży są zatem niejako przypisane do jej egzystencji. Oddziałują nie tylko na przebieg jej dojrzewania, ale także wyznaczają społeczno-kulturowy kontekst dorastania młodego człowieka. Przyczyny uciekania się adolescentów do tego rodzaju praktyk mogą być rozmaite, począwszy od biologicznych predyspozycji (nie mają oni pełnej kontroli hamującej oraz umiejętności tworzenia długodystansowych planów życiowych ${ }^{16}$ ), a na psychospołecznych skończywszy (zaspo-

${ }^{11} \mathrm{~K}$. Ostaszewski, Podstawy teoretyczne profilaktyki zachowań problemowych młodzieży, [w:] Diagnostyka, profilaktyka, socjoterapia w teorii i praktyce pedagogicznej, red. M. Deptuła, Bydgoszcz 2005, s. 112-113.

${ }_{12}$ J.A. Grunbaum i in., Youth risk behavior surveillance - united states, MMWR Surveill Summary, 2004, 55 s. 1; A. Siudem, Zachowania ryzykowne młodzieży gimnazjalnej, Psychologia Rozwojowa, 2013, 18 s. 69-85.

${ }^{13}$ U. Beck, Społeczeństwo ryzyka. W drodze do innej nowoczesności, Warszawa 2002.

${ }^{14}$ Z. Melosik, Młodzież i styl życia. Paradoksy poptożsamości, [w:] Młodzież, styl życia i zdrowie. Konteksty i kontrowersje, red. Z. Melosik, Poznań 2001, s. 34-36.

${ }^{15}$ A. Cybal-Michalska, Tożsamość młodzieży w perspektywie globalnego świata. Studium socjopedagogiczne, Poznań 2006, s. 69.

${ }^{16}$ A. Oleszkowicz, A. Senejko, Psychologia dorastania. Zmiany rozwojowe w dobie globalizacji, Warszawa 2013, s. 115-117. 
kojenie potrzeb życiowych, realizacja zadań rozwojowych, radzenie sobie ze stresem ${ }^{17}$, motywy: ucieczkowe, konformistyczne, egzystencjalne, poszukiwania, hedonistyczne, prestiżowe i snobistyczne ${ }^{18}$ ).

Przytoczone tytuły ekranizacji można podzielić na kilka podgrup w zależności od rodzajów zachowań ryzykownych, jakich dotyczą. Pierwsza z nich odnosi się do działań związanych z nadużywaniem substancji psychoaktywnych przez młodzież. Najstarsza z tego zbioru pozycja z 1981 roku, będąca adaptacją filmową książki dokumentalnej zatytułowanej My, dzieci z dworca Zoo reżyserii U. Edla, to „Christiane F. - My, dzieci z dworca Zoo”, prezentuje biografię młodziej narkomanki z Berlina Zachodniego, dla której sposobem na zdobycie pieniędzy na codzienną dawkę narkotyku są prostytucja i kradzież. Ukazuje specyfikę życia ludzi uzależnionych, robiących wszystko dla zaspokojenia "głodu", przechodzących przez szereg nieskutecznych odwyków oraz wracających do nałogu. Kolejnym filmem odsłaniającym ciemne strony oraz konsekwencje nałogu jest „Requiem dla snu”. Przytoczone losy jego bohaterów prezentują odmienne od zazwyczaj ukazywanego oblicza „,tożsamości typu amerykańskiego" ${ }^{\prime 19}$ zorientowanej na sukces, pełnej optymizmu, przekonanej o braku ograniczeń dla swoich możliwości, ponieważ ich historia nie zostaje zwieńczona szczęśliwym zakończeniem. "Cześć Tereska” to obraz polskiej młodzieży stanowiący wizję R. Glińskiego. Ten wyemitowany w 2001 roku, zrealizowany na czarno-białej taśmie, dramat psychologiczny opowiada historię nastolatki pochodzącej z niezamożnej rodziny. Trudności w domu rodzinnym oraz brak wsparcia dorosłych sprawiają, iż Teresa czuje się osamotniona i zdana wyłącznie na siebie. Wpada w nieodpowiednie towarzystwo, które zachęca ją do kłamstw, kradzieży, palenia papierosów oraz picia alkoholu, w wyniku czego traci swoją szansę na wyrwanie się ze środowiska pochodzenia. Natomiast „Trzynastka” to przykład amerykańskiego filmu w reżyserii C. Hardwicke z 2003 roku. Opowiada historię trzynastoletniej Tracey - wzorowej uczennicy, która w wyniku rozwodu rodziców oraz przyjaźni z Evie zmienia się w zbuntowaną nastolatkę poszukującą mocnych wrażeń, niestroniącą od alkoholu, narkotyków, wagarów, kradzieży oraz przypadkowego seksu.

Druga wyróżniona podgrupa odnosi się do zjawiska ryzykownych zachowań seksualnych prezentowanych przez adolescentów. "Świnki” reżyserii również R. Glińskiego z 2009 roku opowiadają historię szesnastoletniego

${ }^{17}$ B. Woynarowska, Wspótwystępowanie palenia tytoniu i pica alkoholu w zespole zachowań ryzykownych u młodzieży szkolnej. Tendencje zmian w latach 1990-2002, Alkoholizm i Narkomania, $2004,17,1-2$, s. 29-43.

${ }^{18}$ I. Obuchowska, Drogi dorastania, Warszawa 1996.

${ }^{19}$ Z. Melosik, Wychowanie obywatelskie: nowoczesność, ponowoczesność, [w:] Wychowanie obywatelskie, Studium teoretyczne, porównawcze i empiryczne, red. Z. Melosik, K. Przyszczypkowski, Torun - Poznań 1998, s. 50-51. 
chłopca Tomka, który dążąc do spełniania finansowych zachcianek swojej sympatii decyduje się na oddawanie się dorosłym mężczyznom $\mathrm{w}$ zamian za pieniądze. Podczas jednego z wyjazdów pada ofiarą gwałtu. Wydarzenie to sprawia, iż sam staje się pośrednikiem pomiędzy nastoletnimi chłopcami a zainteresowanymi nimi przedstawicielami płci męskiej. Po tragicznej śmierci swojego kolegi - Ciemnego dokonuje śmiertelnej zemsty na gwałcicielu. "Galerianki" są ekranizacją autorstwa K. Rosłaniec z 2009 roku, poruszającą problem prostytucji nieletnich dziewcząt oferujących swoje usługi seksualne $\mathrm{w}$ centrach handlowych $\mathrm{w}$ zamian za kupno wybranych przez nich przedmiotów bądź pieniądze. Z kolei w 2010 roku na ekranach francuskich kin pojawił się film „Studentki” reżyserii E. Bercot odnoszący się do zjawiska nierządu występującego wśród społeczności studenckiej. Przedstawia opartą na faktach historię Laury, która ze względu na problemy finansowe decyduje się na seksualne spotkania z mężczyznami za pieniądze. Rok później M. Szumowska prezentuje "Sponsoring”, który obnaża złożoną naturę tego fenomenu polegającego na samodzielnym wyborze partnera przez call-girls - osobę świadczącą usługi seksualne w zamian za gratyfikacje finansowe.

Z kolei trzecia podgrupa związana jest z przestępczością oraz próbami samobójczymi. „Sala samobójców” - film z 2011 roku w reżyserii J. Komasy opowiada historię nastoletniego chłopca wyróżniającego się niezwykłą wrażliwością emocjonalną. Dominik Santorski nie mogąc odnaleźć się w realnej rzeczywistości, w której posądzany jest przez znajomych o skłonności homoseksualne, znajduje swoje miejsce w świecie wirtualnym. Spędza w nim liczne godziny oddając się swojemu fikcyjnemu życiu, co w efekcie prowadzi do uzależnienia, absencji szkolnej oraz depresji chłopca, a w konsekwencji do jego śmierci. $W$ tym samym roku pojawia się film amerykańskiej produkcji „Dziewczyńskie porachunki” reżyserii S. Gyllenhaal, zainspirowany prawdziwymi wydarzeniami, odnoszący się do zjawiska agresji wśród dziewcząt. Szesnastoletnia, wyróżniająca się nieśmiałością, Haley dążąc do zdobycia popularności w szkole, nawiązuje przyjaźń z grupą dziewcząt, na temat których nieprzychylnie wypowiada się na jednym z portali społecznościowych, zanim ich relacje stają się bardziej zażyłe. $W$ wyniku tego nieporozumienia koleżanki postanawiają dotkliwe pobić nastolatkę i umieścić nagranie z wydarzenia w sieci internetowej. K. Stadnik i A. Wójtewicz zauważają, iż zjawisko agresji fizycznej jest coraz bardziej popularne wśród dziewcząt, bowiem "często stają się uczestniczkami walk i bójek z przedstawicielkami tej samej płci w tym samym wieku, które zazwyczaj znają"20. Uwarunkowań tego rodzaju praktyk można dopatrywać się w różnych czynnikach, jak na przykład zazdrość, rywalizacja o partnera, ocena prezentowanych zachowań seksual-

${ }^{20}$ K. Stadnik, A. Wójtewicz, Anielice czy diablice? Warszawa 2009, s. 157. 
nych ${ }^{21}$, a mechanizm ten w poprawny sposób został ukazany w przytoczonej ekranizacji. Film „Obietnica”, który pojawił się na ekranach kin w 2014 roku opowiada historię nastolatków Lilki i Janka. Chłopiec składa dziewczynie obietnicę, iż udowodni jej swoją miłość poprzez pozbycie się Angeliki - osoby, z którą zdradził swoją partnerkę, co (jak można przypuszczać) przyczynia się do tragedii.

W przedstawionych ekranizacjach wyłania się dramatyczny obraz młodzieży - samotnej, nieposiadającej wystarczającego wsparcia ze strony dorosłych, $\mathrm{w}$ tym także najbliższych, zdolnej do prezentowania nie zawsze odpowiednich zachowań tylko po to, by zdobyć akceptację ze strony rówieśników, zyskać uwagę innych ludzi. W ich rodzinnych domach piętrzą się różnego rodzaju trudności, począwszy od niekorzystnej sytuacji finansowej, poprzez konflikty z rodzeństwem, a na niezbyt udanych relacjach z rodzicami skończywszy. Warto zauważyć, iż niski status socjoekonomiczny w przypadku wielu bohaterów stanowił jedną z przyczyn ich życiowych niepowodzeń, jednak nie ma większego znaczenia jeśli chodzi o dokonywanie przez nich niewłaściwych wyborów. Świadczy o tym przykład Dominika - dobrze usytuowanego finansowo bohatera "Sali samobójców”, jak i Tereski z filmu „Część Tereska”, czy Tomka - postaci ze „Świnek” - mieszkańców blokowisk. Cała trójka nastolatków przeżywa podobne trudności okresu dorastania, a ich decyzje niosą za sobą niekorzystne konsekwencje dla jakości ich egzystencji. Bohaterowie są gotowi żyć na bakier z prawem, przejawiać zachowania niemieszczące się $\mathrm{w}$ granicach społecznej akceptacji tylko po to, żeby chociaż na chwilę zaistnieć w świecie, stać się kimś w swojej ocenie ważnym. Poczucie alienacji oraz pragnienie identyfikacji z grupą przyczynia się do gonitwy za atrybutami powierzchownej rzeczywistości.

Kino niejednokrotnie naświetla problem nastoletnich ciąż, które również są zaliczane do grona zachowań ryzykownych, co ukazane jest między innymi w produkcjach "Juno", „Love, Rosie”, , Bejbi blues”, „Hej, skarbie” oraz "Prawdziwe dziecko". Owe filmowe opowieści można podzielić na dwie kategorie odsłaniające dramatyczną stronę wczesnego macierzyństwa oraz ujmujące daną okoliczność $\mathrm{w}$ afirmatywnych barwach. Właśnie $\mathrm{w}$ ten nietypowy sposób niniejszą problematykę nakreśla wypromowany w 2007 roku film "Juno", prezentujący losy tytułowej bohaterki, która decyduje się na oddanie swojego dziecka rodzinie zastępczej. Prowadzona w nieoceniający, momentami nawet humorystyczny sposób narracja odzwierciedla przemiany zachodzące zarówno w Juno, jej relacji z Bleekerem (ojcem dziecka) oraz w całej rodzinie zaangażowanej w sytuację nastolatków. Wyświetlony w 2014 roku film „Love, Rosi” reżyserii C. Dittera ilustruje co prawda historię miłości Rosie

${ }^{21}$ Tamże, s. 157-161. 
i Alexa, jednak pojawia się w nim również wątek wczesnego macierzyństwa, które staje młodej kobiecie na drodze do realizacji wymarzonej ścieżki kariery zawodowej. Dziewczyna dokonuje wyboru o podjęciu wyzwania zostania samotną matką, co wiąże się z różnego rodzaju trudnościami - samodzielne mieszkanie, praca, rezygnacja ze studiów. Adaptacja powieści C. Ahern Na końcu tęczy niesie za sobą ukryte i jednocześnie zaskakujące przesłanie, iż w rzeczywistości, która „relatywizuje sama siebie w swojej natychmiastowości i jednoczesności występowania "niemal wszystkiego»" 22 cierpliwość oraz konsekwencja mogą zostać zwieńczone sukcesem.

„Bejbi blues” to kolejna ekranizacja przytaczanej wcześniej polskiej reżyserki K. Rosłaniec, której premiera miała miejsce w 2012 roku, prezentuje tragiczną w skutkach historię nastoletnich rodziców Natalii i Kuby. Kiedy matka dziewczyny postanawia wyjechać do pracy w Niemczech, zostawia mieszkanie dwojgu młodym ludziom z dzieckiem. Z pewnością nie można ich uznać za tradycyjną parę przykładnie opiekującą się swoim potomstwem, bowiem w ich codzienność wpisane są imprezy, alkohol oraz narkotyki. Splot różnorodnych wydarzeń doprowadza do śmierci dziecka i umieszczenia jego matki w zakładzie psychiatrycznym. Odbiorcę filmu z pewnością zaskoczy fakt, iż Natalia zamiast załamania i refleksji nad swoim postępowaniem proponuje Kubie zajście w kolejną ciążę, na co chłopiec przystaje. „Hej, skarbie” to amerykański film z 2009 roku reżyserii L. Danielsa ukazujący losy 16-letniej Clareece Jones wykorzystywanej seksualnie przez ojca oraz źle traktowanej przez matkę. Jej pierwsze dziecko cierpi na zespół Downa, natomiast na krótko przed porodem drugiego dowiaduje się, iż została zarażona wirusem HIV. Dziewczyna boryka się z ogromem trudności, zostaje wydalona ze szkoły, w której nie odnosi żadnych sukcesów edukacyjnych, nie otrzymuje należytego wsparcia w dysfunkcyjnym domu, dlatego jej sposobem na radzenie sobie z problemami okazuje się ucieczka w świat marzeń. Dramat obyczajowy „Prawdziwe dziecko” z 2005 roku reżyserii P. Wernera przedstawia sytuację nastoletniej Jacey wydającej na świat Charliego, która rozważając różne opcje działania, w wyniku pomocy udzielonej jej przez mamę oraz jedną z nauczycielek, dojrzewa do decyzji o byciu matką i samodzielnym wychowaniu dziecka.

Ekranizacje te zawierające zarówno wątki dramatyczne, jak i komediowe nakreślają obraz młodych matek, które same jeszcze będąc dziećmi, stają przed zadaniem wzięcia odpowiedzialności za życie drugiej osoby. Okres dojrzewania to czas wielu przemian odnoszących się między innymi do sfer: biologicznej, psychologicznej, społecznej, kulturalnej oraz seksualnej. Ich procesualny

${ }^{22}$ Z. Melosik, T. Szkudlarek, Kultura, tożsamość i edukacja. Migotanie znaczeń, Kraków 1998, s. 21. 
charakter sprawia, że przebiegają one bez względu na próby zahamowania, ograniczenia, bądź nadania im określonej formy. M. Beisert podkreśla, iż „pierwsze kilkanaście lat rozwoju seksualnego tworzy fundament dla dorosłej seksualności"23, która przebiega w interakcji z rytmem psychiczno-fizycznym. Temu przyspieszonemu procesowi „stawania się dorosłym” w przypadku nastoletniego macierzyństwa towarzyszą liczne dylematy, często będące źródłem kryzysów dla młodego człowieka. Bohaterki filmów nie zawsze mogą liczyć na wsparcie dorosłych, ojców dzieci oraz zrozumienie środowiska, które bardzo często okazuje się kluczowe w ich sytuacji. Oprócz tego, muszą zmierzyć się z problemami mieszkaniowymi, ekonomicznymi, szkolnymi, a nierzadko także prawnymi i psychologicznymi. Ciąża niesie za sobą wiele istotnych zmian dla nastolatki, wśród których warto wspomnieć o reakcjach otoczenia, podejmowanych zobowiązaniach, a także trudnych do zaakceptowania przeobrażeniach fizycznych. W przykrych chwilach sposobem na radzenie sobie z obecną sytuacją jest dla nich ucieczka w świat marzeń i fantazji. Opowieści te prezentują metamorfozy kluczowych postaci, które biorą życie we własne ręce i stawiają czoła wyzwaniu wczesnego macierzyństwa.

W kontekście prowadzonych rozważań warto dodać, iż ekranizacje przedstawiające zachowania ryzykowne wśród młodzieży oraz ich społeczne i jednostkowe konsekwencje mogą mieć istotną wartość prewencyjną dla oglądających je osób. W okresie adolescencji następuje kształtowanie się światopoglądu oraz postaw, stanowiących podstawę dla dalszych wyborów jednostki. Badania ankietowe przeprowadzone przez W. Adamczyka dowodzą, iż w znacznym stopniu warunkowane są one przez dane pochodzące z filmów kinowych oraz telewizyjnych. Udział informacji pochodzenia ekranowego w całości wiedzy o świecie szacuje on nawet na poziomie 37,5\% (odsetek ten jest niższy dla młodzieży akademickiej) ${ }^{24}$. Można zatem przypuszczać, iż człowiek mający kontakt z różnego rodzaju produkcjami kinowymi, na ich postawie kształtuje nie tylko przekonania na temat otaczającej go rzeczywistości i swojego w nim miejsca, ale także odnośnie własnej osoby. Siły oddziaływania filmu dowodzą także słowa E. Aronsona, zgodnie z którymi "selektywne wysuwanie pewnych tematów na pierwszy plan sprawia, iż środki masowego przekazu mogą oddziaływać na późniejsze wydarzenia - a nie tylko informowanie o nich" ${ }^{25}$.

Kolejną wyróżnioną grupę stanowią filmy ukazujące specyfikę życia szkolnego, w którym uczestniczą adolescenci. Szkoła stanowi płaszczyznę ich

${ }^{23}$ M. Beisert, Rozwojowa norma seksuologiczna jako kryterium oceny zachowań seksualnych dzieci i młodzieży, Dziecko Krzywdzone, 2006, 16, s. 9.

${ }^{24}$ W. Adamczyk, Rola filmu w kształtowaniu standardów osobistych młodzieży szkolnej, [w:] U podstaw dialogu o edukacji, red. A. Karpińska, Białystok 2003, s. 221-231.

${ }^{25}$ E. Aronson, Człowiek istota społeczna, przekł. J. Radzicki, Warszawa 2006, s. 68. 
życia, której poświęcają znaczącą część swojego czasu. Odnoszą w niej zarówno sukcesy, jak i porażki, nawiązują relacje interpersonalne oraz zdobywają wiedzę. W przypadku wielu ekranizacji filmowych przestrzeń szkolna stanowi tylko tło dla prawdziwych rozterek okresu dorastania, takich jak zdobycie uznania rówieśników, buntu wobec dorosłych oraz radzenie sobie z tragicznymi wydarzeniami, których padają ofiarą. W tym miejscy należy wskazać na takie pozycje jak: ,The Duff [\#ta brzydka i gruba]”, ,'Łatwa dziewczyna”, ,"21 Jump Street”, „Wredne dziewczyny”, „Charlie”, „Młodzi gniewni”, „Wolność słowa”, ,Egzamin dojrzałości”, ,Nasza klasa”, ,Ucieczka w milczenie”, „W ciszy”, „2:37”, ,King Jack”, „Plac zabaw”, ,Mając 17 lat”.

Pierwsza podgrupa filmów eksponuje działania podejmowane przez adolescentów celem zaspokojenia trzech zasadniczych potrzeb uaktywniających się $\mathrm{w}$ środowisku społecznym, określonych przez A.H. Maslowa mianem potrzeb „bezpieczeństwa”, "przynależności” i „uznania” ${ }^{26}$. Ich spełnienie okazuje się szczególnie istotne w świecie, w którym „ludzie pragną być nie tyle szanowani, ile podziwiani" 27 , a zatem zdobycie popularności staje się jednym z elementów sukcesu. Bianka główna postać z filmu reżyserii A. Sandel z 2015 roku „The Duff [\#ta brzydka i gruba]” to dziewczyna obdarzona umiejętnością wnikliwej analizy sytuacji społecznych i relacji międzyludzkich. Kiedy orientuje się, iż stanowi obiekt wyzwisk i drwin ze strony rówieśników, a koleżanki przebywają w jej towarzystwie tylko po to, by stwarzać korzystniejsze wrażenie $\mathrm{w}$ otoczeniu, postanawia to zmienić i stawić czoła szkolnej rzeczywistości. Postanowienie nastolatki niesie za sobą szereg konsekwencji emocjonalnych i społecznych, które odczuwa także partycypując $\mathrm{w}$ przestrzeni internetowej. Wykazując się pewnością siebie oraz niemałą odwagą, po licznych perypetiach, dziewczyna osiąga zamierzony cel. Szkoła średnia widziana oczyma reżysera W. Glucka w filmie "Łatwa dziewczyna" z 2010 roku jest miejscem, w którym powszechne są plotki oraz ostracyzm wobec każdej osoby funkcjonującej niezgodnie z powszechnie przyjętą konwencją. Olive - kluczowa postać, w wyniku nieszablonowych działań, łamie ową zasadę, podobnie jak Cady - bohaterka "Wrednych dziewczyn”, czy Charlie - bohater produkcji o takim samym tytule. Natomiast „21 Jump Street" to film o młodych mężczyznach rozpoczynających karierę w szeregach amerykańskiej policji. Otrzymując zadanie rozpracowania działań dealerów narkotyków, zobowiązani są wcielić się w postaci licealistów. Podczas wykonywania tej tajnej misji, powracają ich szkolne doświadczenia, związane ze staraniami o odpowiednią pozycję $\mathrm{w}$ grupie oraz akceptację ze strony rówieśników.

${ }^{26}$ Patrz: A.H. Maslow, Motywacja i osobowość, Warszawa 2006.

${ }^{27}$ Z. Melosik, Kultura popularna i tożsamość młodzieży. W niewoli władzy i wolności, Kraków 2013, s. 262. 
W zbliżonej narracji oscylującej wokół motywu zmiany, jednak z wyeksponowanym motywem buntu wobec dorosłych i zastanego porządku w świecie, prowadzone są dwa kolejne filmy „Młodzi i gniewni” z 1995 roku oraz „Wolność słowa” z 2007 roku, powstałe na podstawie powieści. Opowiadają one historie dwóch nauczycielek stosujących niekonwencjonalne metody nauczania oraz wyróżniających się ogromną wiarą w swoich uczniów pochodzących z trudnych środowisk społecznych. W szkole przepełnionej przemocą, uprzedzeniami oraz konfliktami, młodzież określana mianem sprawiającej trudności wychowawcze odkrywa swoje zasoby oraz możliwości sprawcze mogące pomóc im odmienić swój los. W równie optymistycznym tonie prowadzona jest ekranizacja filmu „Egzamin dojrzałości" reżyserii B. Robbinsa z 2004 roku. Ukazuje perypetie kilku młodych ludzi, którzy dążąc do spełnienia swoich życiowych marzeń, postanawiają zbuntować się wobec systemu i wykraść pytania egzaminu maturalnego z Princeton Testing Center. Podczas realizacji tego ryzykownego planu w każdym z nastolatków dokonują się przemiany; pobudzają refleksję nad sobą i dojrzewają do stwierdzenia, iż wysoki wynik testu nie zagwarantuje im szczęścia. Z kolei „Nasza klasa” to dramatyczna estońska opowieść autorstwa I. Raaga z 2007 roku o szesnastoletnich Joosepie i Kasparze, którzy podejmują próbę stawienia czoła swoim szkolnym prześladowcom. Trafnie ilustruje mechanizm, zgodnie z którym osoba doświadczająca przemocy sięga po nią $\mathrm{w}$ odwecie.

Akcja takich filmów, jak „Ucieczka w milczenie”, „W ciszy”, „2:37”, „King Jack”, „Plac zabaw”, „Mając 17 lat” co prawda rozgrywa się w szkole, jednak stanowi wyłącznie kontekst dla rzeczywistych trudności przeżywanych przez bohaterów, w przypadku których padają oni ofiarą innych osób. Trzy pierwsze tytuły dotyczą problemu molestowania seksualnego. „Ucieczka w milczenie” amerykański dramat z 2004 roku reżyserii J. Sharzer ukazuje losy trzynastoletniej Melindy, która popada w depresję i traci akceptację grupy po traumatycznych wydarzeniach zaistniałych podczas wakacji, gdzie $\mathrm{w}$ wychodzeniu $\mathrm{z}$ owej sytuacji pomocne okazują się zajęcia z panem Freemanem. Z kolei ekranizacje "W ciszy” oraz "2:37" opisują zjawisko wykorzystania seksualnego dziewcząt przez członków rodziny. „King Jack” to realistyczna opowieść z 2015 roku o przemianach oraz zadaniach związanych z dorastaniem reżyserii F. Thompsona. Tytułowy Jack jest zwyczajnym chłopem przeżywającym pierwsze rozterki miłosne, zaznaczającym swoją aktywność w wirtualnym świecie, a także dopuszczającym się łamania różnego rodzaju norm społecznych. Dodatkowym kłopotem, z którym zobowiązany jest się uporać, okazuje się zastraszający oraz nękający go Shane. Chłopiec nikomu nie mówi o swoich strapieniach, nawet kiedy zostaje dotkliwie pobity. Dlatego, w owej adaptacji można dopatrywać się 
przesłania związanego z milczeniem nastolatków i dokładaniem przez nich starań, by pewne informacje nie przedostały się do „świata dorosłych". Wyreżyserowany w 2016 roku przez B.M. Kowalskiego polskiej produkcji „Plac zabaw" prezentuje nie tylko akt pornograficznej agresji z udziałem uczniów kończących szóstą klasę szkoły podstawowej, ale także prawidłowości towarzyszące adolescencji, takie jak labilność emocjonalna, pierwsze zauroczenie, przekleństwa oraz bunt. Natomiast francuska ekranizacja A. Téchiné z 2016 roku "Mając 17 lat” nakreśla niejednoznaczną specyfikę więzi pomiędzy Damienem oraz Thomasem, zmagających się ze sobą i rywalizujących w klasie, którzy wdają się w różnego rodzaju bójki, jednocześnie są zmuszeni zamieszkać w jednym domu.

Środowisko szkolne prezentowane $\mathrm{w}$ przytoczonych propozycjach filmowych nie jest łatwą przestrzenią dla nastolatka. Obowiązują $w$ niej określone zasady wyznaczane nie tylko przez system edukacji, ale przede wszystkim przez tzw. ukryty program szkoły oraz samych rówieśników. Młody człowiek dąży do osiągnięcia satysfakcjonującej pozycji w grupie oraz uzyskania aprobaty ze strony rówieśników, aby zaspokoić potrzebę akceptacji, bezpieczeństwa, a w konsekwencji także samorealizacji. Aspiracje te wymagają od niego różnorodnych działań, które niejednokrotnie wiążą się z koniecznością rozstrzygania niełatwych dylematów. Uznanie kolegów i koleżanek, ich zrozumienie oraz wsparcie okazują się pomocne dla dorastającej jednostki nie tylko w odnalezieniu swojego miejsca w świecie, ale także dookreśleniu własnego „Ja”. W prowadzonych rozważaniach nie należy także pomijać, często drugoplanowej, jednak także istotnej roli dorosłych - nauczycieli, rodziców, którzy towarzyszą młodemu człowiekowi w procesie tranzycji do dorosłości, służąc radą oraz wsparciem. Każdy adolescent $\mathrm{w}$ mniej lub bardziej świadomy sposób musi poradzić sobie $\mathrm{z}$ dokonującymi się przemianami w swoim życiu. Pomocne w przypadku realizacji tego zadania okazują się wiara we własne możliwości sprawcze oraz konsekwentne dążenie do celu.

Filmy ukazujące specyfikę egzystencji współczesnego pokolenia millenialsów, określanego także mianem Pokolenia Y, to między innymi „Frances $\mathrm{Ha}$ ",Palo alto", „Bilng ring”, , Dziewczyna na krawędzi”, , Szatan kazał tańczyć”, , Nerve”. „Frances Ha” stanowi francuską opowieść z 2012 roku o dojrzewaniu do doniosłych życiowo decyzji oraz dążeniu do realizacji marzeń. Pokazuje wycinek biografii Frances - energicznej tancerki, koncentrującej się na tym, co dzieje się „tu i teraz”. „Palo alto” ukazuje życie amerykańskich nastolatków, korzystających z możliwości dostarczanych im przez współczesną rzeczywistość, jak imprezy, alkohol, szybka jazda samochodem, afekt do nauczyciela, ryzykowne zabawy, do których przypisana jest „niespójność, niekonsekwencja postępowania, fragmentaryzacja i epizodyczność rozmaitych 
sfer aktywności jednostek”28. Z kolei „Bling ring” S. Coppoli z 2013 roku prezentuje postaci zorientowane na konsumpcjonizm, marzące o sławie i wielkiej karierze nastolatków okradających domy sławnych gwiazd, nie podejmując namysłu nad konsekwencjami swoich działań. Ich zainteresowania oscylują wokół plotkarskich portali internetowych oraz gazet, w których śledzą poczynania ulubionych celebrytów. Film stworzony w 2015 roku przez J. Silverman o osobie funkcjonującej w świecie mediów, która pada ofiarą cyberprzemocy, w wyniku czego zaczyna siebie krzywdzić na wiele różnych sposobów, to „Dziewczyna na krawędzi”. Nastoletnia Hannah przyzwyczajona do partycypowania w dynamicznej rzeczywistości, trafia do ośrodka terapeutycznego położonego w znacznej odległości od miejskiego zgiełku, gdzie stara się poukładać swoje życie. Przykładem polskiej adaptacji ukazującej konsekwencje podążania za sukcesem w świecie mediów jest „Diabeł kazał tańczyć” z 2016 roku, reżyserii K. Rosłaniec. Karolina dzięki napisanej przez siebie powieści staje się sławna, wskutek czego pojawia się w różnych miejscach, do których bywa zapraszana. Można odnieść wrażenie, iż jest człowiekiem spełnionym, zadowolonym z własnych osiągnięć, jednak tak naprawdę nieustannie stara się odkryć swoje "ja” oraz dookreślić swoją rolę i miejsce we współczesności, w tym celu eksperymentując z różnego rodzaju używkami. Tajemnice zdominowanego postępem technologicznym świata ujawnia "Nerve” - film reżyserii H. Joost i A. Schulman z 2016 roku, obrazujący losy nieśmiałej Vee, która zdobywa się na odwagę zagrania w "prawdę i wyzwanie”, zachęcającą użytkowników do popełniania kolejnych, coraz poważniejszych wykroczeń, których przebieg śledzony jest przez użytkowników Internetu.

Przedstawiciele tej grupy społecznej to osoby, których istotnym elementem egzystencji jest sieć internetowa - główna przestrzeń ich partycypacji i aktywności. To w niej zawierają nowe znajomości, robią zakupy oraz nierzadko wykonują swoją pracę. Wyróżnia ich wysoki poziom elastyczności i umiejętności szybkiego adaptowania się do zastanych warunków, pewność siebie, przedsiębiorczość oraz przekonanie o posiadanych kompetencjach, zaś realizowany przez nich styl życia, w który nieodparcie wpisana jest konsumpcja oraz poszukiwanie wrażeń, stanowi źródło ich satysfakcji i spełnienia. Podobne cechy charakteryzują bohaterów przytoczonych ekranizacji filmowych - są to osoby o niskim poziomie krytycyzmu w stosunku do siebie, jednak o szeregu wymagań względem otoczenia, co staje się źródłem ich niepowodzeń oraz dylematów. Życie młodych ludzi w tym przypadku koncentruje się na eksperymentowaniu. Wpisane jest w nie „poczucie otwartości życia" ${ }^{29}$, wyrażające się w możliwości popełniania błędów, odnoszenia

${ }^{28}$ Z. Bauman, Ponowoczesne wzory osobowe, Studia Socjologiczne, 1993, 2(19), s. 7.

${ }^{29}$ L. Kołakowski, Mini wykłady o maxi sprawach, Seria druga, Kraków 2000, s. 64. 
porażek, dokonywania zmian i korzystaniu ze swojej wolności, co ma doprowadzić do urzeczywistnienia ich celów i pragnień. Funkcjonują oni niejako w stanie „multifrenii - porywającym jednostkę w kapryśny, pełen kaskad, progów i wirów nurtów bycia" ${ }^{30}$. Współczesny człowiek to osoba wielozadaniowa, niejednokrotnie pełniąca masę rozmaitych ról. Młodzież przygotowująca się do ich sprawowania czerpie wzorce z różnorodnych źródeł, w tym także filmowych.

Okres dojrzewania jest również czasem krystalizacji planów odnośnie dalszego życia oraz doświadczania pierwszych miłosnych rozterek. Niniejszych wątków tematycznych nie brakuje w filmach: „Kochaj i tańcz”, "Street dance”, "Step up", „Footloose”, ,Legalna blondynka”, „Diabeł ubiera się u Prady", ,Absolwentka", „Do zaliczenia", „Cudowne tu i teraz", będących opowieściami o marzeniach oraz zakochaniu. Ich wspólną cechę stanowi zakotwiczenie w "amerykańskim śnie”, którego istota tkwi w tym, iż „potrafi przejąć ze świata wszystko to, co jest ekscytujące, co nowe i świeże, co może mieć wartość $\mathrm{w}$ ofercie gotowych do spożycia atrakcyjnych i przyjemnych wrażeń" ${ }^{31}$ oraz w przekonaniu, że każdy człowiek może odnieść sukces, jeśli tylko tego pragnie. Znajdujące się na czterech pierwszych pozycjach tytuły co prawda oscylują wokół tematu tańca, jednak ukazują losy osób walczących z własnymi słabościami, poznających prawdę o sobie, zmierzających do realizacji celów. „Legalna blondynka” produkcja, która doczekała się swojej kontynuacji, niesie za sobą przesłanie, iż piękno fizyczne może iść w parze z rozumem. Prezentuje bowiem osiągnięcia Elle Woods, która pomimo specyficznego sposobu bycia oraz ubierania się wieńczy sukcesem obrane przedsięwzięcia. Z kolei w specyfikę ponowoczesnej tożsamości typu supermarket doskonale wpisuje się postać Andrei Sachs - bohaterki filmu „Diabeł ubiera się u Prady", która całkowicie zmienia się po otrzymaniu stażu w nowojorskim Runwayu. Kolejną opowieścią ukazującą zjawisko podwójnej tranzycji z edukacji na rynek pracy oraz z okresu dojrzewania do dorosłości jest „Absolwentka" reżyserii V. Jensona z 2009 roku. Ryden koncentruje się na skrupulatnym odhaczaniu kolejnych punktów swojego długofalowego planu życiowego, który po ukończeniu college'u lega w gruzach, gdyż nie udaje się jej znaleźć wymarzonej pracy, jednak mimo to nie poddaje się i konsekwentnie dąży do obranego celu. Bohaterką pragnącą zmian jest także Brandy Clarke, będąca główną postacią $\mathrm{w}$ amerykańskiej produkcji ekranizacji reżyserii M. Carey z 2013 roku. Stanowi ona przykład wzorowej posłusznej rodzicom i nauczycielom uczennicy, postanawiającej zrealizować stworzoną przez siebie listę szalonych zadań, wśród których znajduje się również przeżycie swojego s. 112.

${ }^{30}$ K.J. Gergen, Nasycone Ja. Dylematy tożsamości w życiu wspótczesnym, Warszawa 2009,

${ }^{31}$ Z. Melosik, Kultura popularna, s. 92. 
pierwszego razu. „Cudowne tu i teraz” reżyserii J. Ponsoldt oddaje kwintesencję egzystencji nastolatków we współczesnej rzeczywistości. Sutter Keely to młody człowiek korzystający z dostępnych mu rozrywek, niedbający o wyniki zdobywane w szkole, który zmienia się ze względu na Aimee.

Nakreślone w przywołanych ekranizacjach sylwetki bohaterów to klasyczne przykłady ponowoczesnych tożsamości wyróżnionych przez Z. Baumana - spacerowicza, włóczęgi, gracza oraz turysty ${ }^{32}$ lub wskazanych przez Z. Melosika - tożsamości globalnej przezroczystej, globalnej każdej, upozorowanej, typu supermarket, najczęściej eksponowanej typu amerykańskiego oraz znacznie rzadziej typu brzytwa ${ }^{33}$. Adolescenci znajdują się w kulminacyjnym momencie podejmowania ważnych decyzji o znaczeniu dla ich dalszej biografii. Prezentują zróżnicowane postawy wobec tego zadania, niektórzy mają jasną wizję swojej przyszłości, do której konsekwentnie dążą, inni żyją spontanicznie, czekając co przyniesie im los. Warto jednak zaznaczyć, iż filmy cechują się szczęśliwymi zakończeniami, które napawają widzów optymizmem, również w odniesieniu do własnej przyszłości.

$\mathrm{W}$ analizie obrazu młodzieży w filmach nie należy również pomijać tych ukazujących jej fantastyczny, nierealny wizerunek, jednak co może zaskakiwać, to właśnie te kinowe propozycje cieszą się najliczniejszym gronem sympatyków ${ }^{34}$. Sprzyjający z nimi widzowie niejednokrotnie identyfikują się z głównym bohaterem; ten typ uczestnictwa odbywa się w dwóch modalnościach wyzwalających określone pragnienia - „być z” lub „być jak”"35. Wśród tego rodzaju ekranizacji nie może zabraknąć takich tytułów, jak: „Zmierzch”, „Zabójcze ciało”, „Harry Potter”, „Carrie”, „Spider-man”, „Dary aniołów: miasto kości”, „Piękne istoty”, „Igrzyska śmierci”, „Dziewczyna w czerwonej pelerynie", "Power Rangers". Wiele z nich doczekało się licznych kontynuacji. Występujący w nich aktorzy przemieniają się w wampiry, wilkołaki, czarownice, czarodziejów, potwory, istoty o ponadludzkich umiejętnościach oraz pozostają ludźmi prezentującymi niezwykłe talenty. Produkcje te obnażają obraz nastolatków o nadprzyrodzonych mocach i zdolnościach, gotowych zarówno do czynienia dobra, jak i zła. Pozornie mogłoby się wydawać, że człowiek potrafiący czarować, tudzież dysponujący nieograniczoną mocą, powinien być pozbawiony życiowych rozterek, staje się jednak oczywiste,

${ }^{32}$ Patrz: Z. Bauman, Ponowoczesne wzory.

${ }^{33}$ Patrz: Z. Melosik, Wychowanie obywatelskie.

${ }^{34} \mathrm{Na}$ poparcie tej tezy warto przytoczyć przykład filmu Saga "Zmierzch: Przed świtem”. Media podają informację, że już po pierwszym weekendzie jego wyświetlania, produkcja ta okazała się jedną z najbardziej dochodowych w historii kina. Podobnych danych dostarczają wiadomości dotyczące dochodów uzyskanych z emisji „Harrego Pottera”.

${ }^{35} \mathrm{~W}$. Adamczyk, Bohater filmowy w percepcji mtodzieży. Film w procesach ksztattowania standardów osobistych uczniów szkolnych i studentów oraz konceptualizacji tworzonego przez nich wizerunku rzeczywistości, Bielsko-Biała 2012, s. 75. 
iż reżyserzy filmowi dbają, aby dostarczyć widzowi odpowiednich emocji podczas seansu. $W$ efekcie, te nadzwyczajne nastolatki również przeżywają dylematy okresu dojrzewania, zabiegają o odpowiednie miejsce w grupie rówieśniczej, kształtują swój światopogląd, często odznaczają się niepewnością oraz niską samooceną, a także doświadczają pierwszych miłości. To właśnie ich przygody stają się źródłem inspiracji dla młodych odbiorców, nierzadko utożsamiają się z nimi, a nawet identyfikują, o czym świadczy między innymi rozwijający się fenomen cosplay.

Jedną z przyczyn popularności fantastycznych postaci jest prawidłowość, w myśl której „bohater filmowy występujący w (...) [filmie fabularnym przyp. LM-S] pojmowany jest przez odbiorcę, jako człowiek bliski, chociaż częściej bliższy marzeniu, aniżeli rzeczywistości realnej"36. Oglądając postaci o nadzwyczajnych właściwościach, widz może zacząć uświadamiać sobie istnienie różnic pomiędzy swoim „Ja realnym" oraz "Ja idealnym", co przyczynia się do poczucia dysonansu oraz dyskomfortu względem własnej samooceny $^{37}$. Jego ocena siebie $w$ takiej sytuacji wypada negatywnie, następstwem czego okazuje się frustracja lub motywacja do pracy nad sobą.

Obraz młodzieży w filmie jest bardzo zróżnicowany. Przedstawia zwyczajnych nastolatków przeżywających trudności związane z okresem dorastania, młodych ludzi znajdujących się w skomplikowanej sytuacji życiowej, podejmujących niekoniecznie odpowiednie decyzje niosące za sobą tragiczne konsekwencje oraz fantastyczne postacie o nadprzyrodzonych zdolnościach. Filmowe opowieści ukazują młodzież stojącą przed ważnym zadaniem stania się osobą dojrzałą. Owa podróż ku dorosłości nie jest jednak prosta i bardzo często na drodze do niej pojawiają się różnego rodzaju trudności i do najczęściej eksponowanych należy zaliczyć te związane z relacjami interpersonalnymi, zabieganiem o uznanie $\mathrm{w}$ grupie rówieśniczej, akceptację, uwagę osób znaczących, w tym także rodziców, ryzykownym eksperymentowaniem (jak sięganie po używki, wczesna inicjacja seksualna), korzystaniem z mediów, dążeniem do osiągnięcia satysfakcjonującego poziomu konsumpcji, co $\mathrm{w}$ wielu przypadkach kończy się łamaniem prawa oraz kradzieżami, czy agresywnymi zachowaniami. Jednakże, bohaterowie filmu to także jednostki sprawcze, pewne siebie, konsekwentnie realizujące zamierzone plany, podążające za marzeniami. Niniejszy obraz młodzieży oprócz filmowej fikcji oraz na wskroś przerysowanych stylów jej życia, ukazuje cechy charakterystyczne dla okresu dorastania oraz nakreśla współczesny kontekst jej egzystencji.

Warto również wspomnieć, iż filmy których bohaterami jest przede wszystkim młodzież można podzielić na przeznaczone dla nastoletnich odbiorców

\footnotetext{
${ }^{36}$ H. Depta, Fabryka snów, s. 8.

${ }^{37}$ W. Adamczyk, Bohater filmowy, s. 92.
} 
oraz których oglądanie jest wskazane dopiero po osiągnięciu przez widza określonego wieku. Niemniej oczywiste jest, iż młodzi ludzie niejednokrotnie uważnie śledzą losy przytoczonych bohaterów. W związku z tym, należy zastanowić się, w jakim stopniu wizerunek adolescentów prezentowany $\mathrm{w}$ filmie oddziałuje na ich sposób myślenia o sobie. Konieczność owego namysłu zostaje uzasadniona tym, iż w okresie dojrzewania zachodzą jedne $\mathrm{z}$ najbardziej znaczących przeobrażeń związanych z obrazem własnej osoby. W. Adamczyk

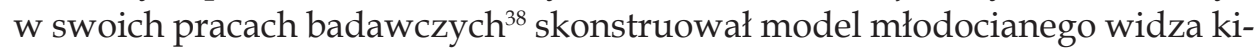
nowego, u którego zmienia się szereg funkcji poznawczych podczas uczestnictwa w seansie filmowym. Wśród nich należy wskazać: młodzieńcze marzenia, ideały, plany życiowe, ciekawość poznawczą, niepokój badawczy, konieczność podejmowania refleksji nad nowymi zagadnieniami, wiedzę adolescenta na temat otaczającej go rzeczywistości i samego siebie, a także towarzyszące im procesy psychologiczne $\mathrm{w}$ postaci utożsamiania się widza $\mathrm{z}$ pierwszoplanowymi bohaterami filmu oraz zaangażowania emocjonalnego i intelektualnego. Uzyskany przez autora materiał empiryczny ukazuje, iż film w znacznym stopniu oddziałuje na kształtowanie światopoglądu młodych ludzi, jak również przyjmowane przez nich wartości oraz percepcję własnej osoby ${ }^{39}$, co dowodzi edukacyjno-wychowawczej funkcji przekazu filmowego w życiu społecznym.

W celu zrozumienia mechanizmu oddziaływania filmu na odbiorcę, warto poddać bliższej analizie poznawczą koncepcję człowieka, dla której najbardziej znaczące były prace J. Brunera, G.A. Kelly'ego i H.A. Simona, A. Newella oraz O. Tichomirowa. Jej istota tkwi w założeniu, iż jednostka jest podmiotem sprawczym, o zdolności do samodzielnego analizowania rzeczywistości, wobec której przyjmuje aktywną postawę badawczą ${ }^{40}$. Oznacza to, iż nie pozostaje on bierny wobec doświadczanych wydarzeń oraz otoczenia, lecz pozyskuje z nich informacje, które następnie przetwarza w wyniku dokonywanych operacji poznawczych. Prawidłowość tę trafnie oddają słowa W. Jakubowskiego, który stwierdza, iż „edukacyjny potencjał utworu nie tkwi $\mathrm{w}$ dziele, to odbiorca decyduje o jego poziomie" ${ }^{41}$. Badacz ten zauważa, że w przypadku odbioru filmu fabularnego istotną rolę odgrywają trzy procesy,

${ }^{38}$ W. Adamczyk, Psychologiczny model percepcji dzieła sztuki filmowej, Kultura i Historia, 2005, 9; tenże, Psychologiczny model widza kinowego. Przyczyny preferencji filmów produkcji amerykańskiej oraz ich skutki wychowawcze wśród młodzieży szkolnej i akademickiej, Bielsko Biała 2005. Warto również zaznaczyć, iż trudu analizy fenomenu oddziaływania filmu na młodzież podjął się również J. Ostaszewski (Patrz: J. Ostaszewski, Rozumienie opowiadania filmowego, Kraków 1999).

39 Odbiorcy filmów przejawiali "poczucie mocy”, znajdujące swoje odzwierciedlenie w tym, iż czuli się silniejsi, bardziej sprawni, byli przekonani o osobistych możliwościach osiągania wyznaczonego celu. W tym procesie istotne znaczenie miały uruchamiające się struktury "Ja idealnego", generujące sposób postrzegania siebie. (W. Adamczyk, Psychologiczny model, s. 301-303).

${ }^{40}$ Patrz: J. Kozielecki, Koncepcje psychologiczne człowieka, Warszawa 1997.

${ }^{41}$ W. Jakubowski, Edukacja w świecie kultury popularnej, Kraków 2006, s. 122. 
jak rozumienie, analiza i interpretacja ${ }^{42}$. Rozumienie odnosi się do przetworzonych przez widza danych na temat fabuły obejrzanej ekranizacji. Analiza wiąże się z krytycznym ustosunkowaniem się do zapamiętanych treści. $\mathrm{Z}$ kolei interpretacja, mająca kluczowe znaczenie $\mathrm{w}$ przypadku wychowawczej funkcji dzieła, pozwala zrozumieć, dlaczego określone dane oraz sceny zostały przedstawione właśnie $\mathrm{w}$ taki, a nie inny sposób. Należy mieć na uwadze, iż jakość i sposób oddziaływania filmu warunkowane są szeregiem różnorodnych czynników, jak: jego jakość, kontekst wydarzeń społeczno-historycznych, oczekiwania i potrzeby odbiorcy, aktualnie przeżywane przez jednostkę sytuacje lub trudności, konieczność dokonywania przez nią wyborów, stopień zaawansowania jej dojrzałości biologiczno-psychologiczno-społecznej, postawy przyjmowanej wobec utworu (biernej, aktywnej) ${ }^{43}$.

Fakt, iż „ludzie mogą wybierać aktorów, z którymi chcą się utożsamiać, lub historie, które ożywią ich fantazje" ${ }^{\prime 4}$, przyczynia się do zjawiska zwielokrotnienia „Ja”. Młody człowiek partycypujący we współczesnej dynamicznej i ambiwalentnej rzeczywistości zobligowany jest do pełnienia wielu różnorodnych ról. Ekranizacje wywołujące refleksję podmiotu dotyczącą własnej osoby uruchamiają struktury jego metawiedzy ${ }^{45}$. Wyraźnego podkreślenia wymaga jednak, iż

proces budowania własnego „ja” jest coraz intensywniej wzbogacany medialnym materiałem symbolicznym, co powoduje, iż żyjemy dzisiaj w świecie, w którym zdolność doświadczania niekoniecznie musi mieć związek z tym, co napotykamy na swojej drodze, z czym obcujemy na co dzieńn ${ }^{46}$.

Prawidłowości tej nie da się prawdopodobnie uniknąć ze względu na to, iż

żyć w świecie, to także opowiadać o nim, o sobie, o innych ludziach, o codzienności i niezwykłości. Narracje znajdujemy w mitach, legendach, opowieściach, powieściach, historii, tragediach, dramatach, obrazach, filmach, fotografiach, komiksach, gazetach, rodzinnych rozmowach ${ }^{47}$.

Dlatego, warto intensyfikować oddziaływania pedagogiczne ukierunkowane na doskonalenie umiejętności medialnych młodych ludzi, związanych nie tylko z bezpiecznym korzystaniem ze środków masowego przekazu, ale także z refleksyjnym przyjmowaniem transmitowanych w nich treści.

${ }^{42}$ Tamże, s. 128.

${ }^{43}$ Tamże, s. 131-152.

${ }^{44}$ K.J. Gergen, Nasycone Ja. Dylematy tożsamości, s. 87.

${ }^{45}$ W. Adamczyk, Bohater filmowy, s. 93.

${ }^{46}$ W.J. Burszta, W. Kuligowski, Sequel. Dalsze przygody kultury w globalnym świecie, Warszawa 2005, s. 231.

${ }^{47}$ Tamże, s. 222. 
W ciągu swojej biografii podmiot kształtuje własne kompetencje kulturowe, które warunkują odbiór przekazów medialnych. Poziom ich rozwoju zależy od zakresu reprezentowanej przez niego wiedzy oraz doświadczeń gromadzonych $w$ wyniku socjalizacji ${ }^{48}$. W tym miejscu warto wspomnieć, iż Z. Korsak dokonuje trafnego spostrzeżenia w kwestii świadomości filmowej, którą postrzega przez pryzmat pewnych przekonań oddziałujących na jednostkowe sądy o świecie oraz przyjmowane przez nią wartości, a mianowicie że w obszarze edukacji niewiele refleksji poświęca się temu, jak należy patrzeć na film i go oceniać ${ }^{49}$. Na potrzeby niniejszej problematyki ukuto termin umiejętności wizualnych (visual literacy), związanych ze zdolnością odczytywania znaczeń przekazywanych za pomocą obrazów. W rozważaniach nim poświęconym podejmuje się dyskusję odnośnie tego, czy stanowią one konsekwencję funkcjonowania człowieka w społeczeństwie oraz czy ich posiadanie wymaga wcześniejszych, sformalizowanych działań przygotowawczych ${ }^{50}$. Oferta kultury masowej staje się atrakcyjna dla widza, ponieważ „nie wymaga szczególnych kompetencji, niemal żadnego wysiłku umysłowego, a przy tym obiecuje tak wiele szczęścia" ${ }^{51}$, co tak naprawdę sprawia, iż obraz młodzieży prezentowany w kinowych produkcjach, formujący się w umysłach odbiorców, charakteryzuje się bliżej nieokreślonym stopieniem subiektywnej interpretacji.

\section{BIBLIOGRAFIA}

Adamczyk W., Rola filmu w kształtowaniu standardów osobistych młodzieży szkolnej, [w:] U podstaw dialogu o edukacji, red. A. Karpińska, Białystok 2003.

Adamczyk W., Psychologiczny model percepcji dzieła sztuki filmowej, Kultura i Historia, 2005, 9. Adamczyk W., Psychologiczny model widza kinowego. Przyczyny preferencji filmów produkcji amerykańskiej oraz ich skutki wychowawcze wśród młodzieży szkolnej $i$ akademickiej, Bielsko-Biała 2005.

Adamczyk W., Bohater filmowy w percepcji młodzieży. Film w procesach ksztattowania standardów osobistych uczniów szkolnych i studentów oraz konceptualizacji tworzonego przez nich wizerunku rzeczywistości, Bielsko-Biała 2012.

Aronson E., Człowiek istota społeczna, przekł. J. Radzicki, Warszawa 2006.

Bauman Z., Ponowoczesne wzory osobowe, Studia Socjologiczne, 1993, 2(19).

Beck U., Społeczeństwo ryzyka. W drodze do innej nowoczesności, Warszawa 2002.

${ }^{48}$ M. Mrozowski, Media masowe. Władza, rozrywka i biznes, Warszawa 2001, s. 28.

${ }^{49}$ Z. Korsak, Świadomość filmowa młodzieży, Zeszyty Naukowe Wyższej Szkoły Pedagogicznej w Bydgoszczy. Studia Pedagogiczne, 1990, 16, s. 37-39.

${ }^{50}$ Patrz: M.F. Cassidy, J.Q. Knowlton, A visual literacy: a failed metaphor? Education Communication and Technology Journal, 1983, 31, 2, s. 67-90.

${ }^{51}$ M. Golka, Aparycje, s. 135. 
Beisert M., Rozwojowa norma seksuologiczna jako kryterium oceny zachowań seksualnych dzieci i młodzieży, Dziecko Krzywdzone, 2006, 16.

Burszta W.J., Kuligowski W., Sequel. Dalsze przygody kultury w globalnym świecie, Warszawa 2005.

Cassidy M.F., Knowlton J.Q., A visual literacy: a failed metaphor? Education Communication and Technology Journal, 1983, 31, 2.

Celiński P., Postmedia. Cyfrowy kod i bazy danych, Lublin 2013.

Cybal-Michalska A., Tożsamość młodzieży w perspektywie globalnego świata. Studium socjopedagogiczne, Poznań 2006.

Depta H., Fabryka snów czy szkoła życia, Warszawa 1986.

Galas B., Młodzież, [w:] Encyklopedia pedagogiczna XXI wieku, red. T. Pilch, t. II, Warszawa 2005.

Gergen K.J., Nasycone Ja. Dylematy tożsamości w życiu współczesnym, Warszawa 2009.

Golka M., Aparycje wspótczesności, Warszawa 2015.

Grunbaum J.A., Kann L., Kinchen S., Ross J., Hawkins J., Lowry R., Harris W.A., McManus T., Chyen D., Collins J., Youth risk behavior surveillance - united states, MMWR Surveill Summary, 2004, 55.

Jakubowski W., Edukacja w świecie kultury popularnej, Kraków 2006.

Kluszczyński R.W., Film, wideo, multimedia. Sztuka ruchomego obrazu w erze elektronicznej, Kraków 2002.

Kołakowski L., Mini wykłady o maxi sprawach, Seria druga, Kraków 2000.

Korsak Z., Świadomość filmowa młodzieży, Zeszyty Naukowe Wyższej Szkoły Pedagogicznej w Bydgoszczy. Studia Pedagogiczne, 1990, 16.

Kosmalska B., Zrozumieć obraz, [w:] Obraz, przestrzeń popkultura. Inspiracje badawcze w polu pedagogiki społecznej, red. M. Ejsmont, B. Kosmalska, M. Mendel, Torun 2009.

Kozielecki J., Koncepcje psychologiczne człowieka, Warszawa 1997.

Maslow A.H., Motywacja i osobowość, Warszawa 2006.

Melosik Z., Wychowanie obywatelskie: nowoczesność, ponowoczesność, [w:] Wychowanie obywatelskie, Studium teoretyczne, porównawcze i empiryczne, red. Z. Melosik, K. Przyszczypkowski, Torun - Poznań 1998.

Melosik Z., Młodzież i styl życia. Paradoksy poptożsamości, [w:] Młodzież, styl życia i zdrowie. Konteksty i kontrowersje, red. Z. Melosik, Poznań 2001.

Melosik Z., Kultura popularna i tożsamość młodzieży. W niewoli władzy i wolności, Kraków 2013.

Melosik Z., Szkudlarek T., Kultura, tożsamość i edukacja. Migotanie znaczeń, Kraków 1998.

Mrozowski M., Media masowe. Wtadza, rozrywka i biznes, Warszawa 2001.

Obuchowska I., Drogi dorastania, Warszawa 1996.

Oleszkowicz A., Senejko A., Psychologia dorastania. Zmiany rozwojowe w dobie globalizacji, Warszawa 2013.

Ostaszewski J., Rozumienie opowiadania filmowego, Kraków 1999.

Ostaszewski K., Podstawy teoretyczne profilaktyki zachowań problemowych młodzieży, [w:] Diagnostyka, profilaktyka, socjoterapia w teorii i praktyce pedagogicznej, red. M. Deptuła, Bydgoszcz 2005.

Panofsky E., Styl i tworzywo w filmie, [w:] Studia z historii sztuki, red. E. Panofsky, wybrał i oprac. J. Białostocki, Warszawa 1971.

Pisarek J., Francuz P., Poznawcze i emocjonalne zaangażowanie widza w film fabularny $w$ zależności od typu bohatera, [w:] Psychologiczne aspekty komunikacji audiowizualnej, red. P. Francuz, Lublin 2007. 
Plisiecki J., Jezzyk filmu i jego mowa, Roczniki Kulturoznawcze, 2010, 1.

Siudem A., Zachowania ryzykowne młodzieży gimnazjalnej, Psychologia Rozwojowa, 2013, 18. Stadnik K., Wójtewicz A., Anielice czy diablice? Warszawa 2009.

Szafraniec K., Boni M. (red.), Młodzi 2011, Warszawa 2011.

Woynarowska B., Wspótwystępowanie palenia tytoniu i picia alkoholu w zespole zachowań ryzykownych u młodzieży szkolnej. Tendencje zmian w latach 1990-2002, Alkoholizm i Narkomania, 2004, 17, 1-2. 